\title{
Corporate Social Responsibility: An Economic and Financial Framework
}

\author{
Geoffrey Heal ${ }^{*}$ \\ Columbia Business School, 616 Uris Hall, 3022 Broadway, New York, NY 10027, U.S.A. \\ E-mail: gmh1@Columbia.edu
}

I analyze corporate social responsibility (CSR) from economic and financial perspectives, and suggest how it is reflected in financial markets. CSR is defined as a programme of actions to reduce externalized costs or to avoid distributional conflicts. It has evolved in response to market failures, a Coasian solution to problems associated with social costs. The analysis suggests that there is a resource-allocation role for CSR programmes in cases of market failure through private-social cost differentials, and also where distributional disagreements are strong. In some sectors of the economy private and social costs are roughly in line and distributional debates are unusual: here CSR has little role to play. Such sectors are outnumbered by those where CSR can play a valuable role in ensuring that the invisible hand acts, as intended, to produce the social good. It can also act to improve corporate profits and guard against reputational risks.

The Geneva Papers (2005) 30, 387-409. doi:10.1057/palgrave.gpp.2510037

Keywords: corporate social responsibility; CSR; risk management; socially responsible investment; SRI; environmental responsibility

Jel classification: D 210, D 610, M 140

\section{Introduction}

Should corporations worry about their social impact? Or should they just go for profits and trust that everything else will fall into place? Apple, Intel and Microsoft did this: in 20 years they created an industry affecting everyone in the developed world, changing lives and businesses, creating billions of dollars in value for shareholders and tens of thousands of jobs for new employees. They contributed massively to society, and did so in the cause of making money for their shareholders. They illustrate well Adam Smith's classic remark that "It is not from the benevolence of the butcher, the brewer, or the baker that we expect our dinner, but from their regard to their own interest." If companies make products that consumers value and price them affordably, making money in the process, what is the need for corporate social responsibility (CSR)?

\footnotetext{
* This paper was prepared for presentation at the 2004 Annual Conference of the Monte Paschi Vita, organized around the topics of corporate governance and corporate social responsibility. Andrea Beltratti, Ray Horton, Bengt Kristrom and Howard Kunreuther have provided some very thoughtprovoking comments, and the students in my Spring 04 course "Business and Society - Doing Well by Doing Good?" greatly sharpened my understanding of these issues.
} 
Tobacco companies sell a poison that is slow-acting and addictive, so they can actually make money while killing their customers, clearly a different case from the tech sector. What about auto and oil companies, which help us experience freedom by means of personal mobility, while polluting the environment and changing the climate? What differentiates the tech sector from tobacco, oil and autos? To understand this we have to see when the interests of corporations are fully aligned with those of society as a whole and when they are in conflict, and for this we have to go beyond Adam Smith, to the concepts of private and social costs. Markets work well for society, aligning corporate and social interests, when a firm's private and social costs are the same, which is more or less the case with the tech sector. However, when corporate and social interests are not aligned, markets do not do such a good job, as is the case with tobacco and, to a lesser degree, oil and autos. This explains the conflict between corporations and society in these sectors. Discords can arise, too, over issues of fairness. What is a fair wage for unskilled labor in Vietnam, or for that matter in the retail sector in the U.S.? As Nike and Wal-Mart know, these are controversial issues. Markets may be efficient but there is no presumption that they are fair, although society values fairness as well as efficiency.

CSR is an important part of corporate strategy in sectors where inconsistencies arise between corporate profits and social goals, or discord can arise over fairness issues. A CSR programme can make executives aware of these conflicts and commit them to taking the social interest seriously. It can also be critical to maintaining or improving staff morale, to the stock market's assessment of a company's risk and to negotiations with regulators. The payoff to anticipating sources of conflict can be very high indeed it can be a matter of survival, as societies penalize companies perceived to be in conflict with underlying values. Asbestos was the tobacco of the 1950s: where is that industry today?

\section{Conflicts between corporations and society}

An understanding of the strengths and weaknesses of competitive markets suggests a role for CSR programmes. Competitive markets are strong - produce efficient outcomes - when private and social costs and benefits are the same. In this case what is most profitable to the corporation is also best for society. In the immortal if overly assertive 1952 words of Charles E. "Engine Charley" Wilson, President of General Motors, "What is good for General Motors is good for America." Another caveat about competitive markets is that they may produce outcomes that appear unfair: provided private and social costs and benefits are aligned they are efficient but not necessarily fair. ${ }^{1}$ Almost all conflicts between corporations and society can be traced to one of these two sources - either discrepancies between private and social costs and benefits, or different perceptions of what is fair. Usually this latter relates to the payment of low-income employees, as in the case of sweatshop allegations against garment and footwear companies or of union-busting allegations against Wal-Mart.

\footnotetext{
${ }^{1}$ The key analytical point here is that a competitive equilibrium is efficient - Pareto efficient - but not necessarily socially optimal if the concept of optimality takes into account the distribution of welfare.
} 
However, we are also beginning to see allegations of unfairness arise in other contexts, such as the claims by New York State Attorney General Elliot Spitzer that contingent commissions to brokers by insurers are unfair to the brokers' clients and involve a conflict of interest on the part of brokers. Similar are his earlier allegations against investment banks concerning their management of internet IPOs. All this is entirely to be expected from a theoretical point of view, for these are precisely the situations where what is best for the corporation is not necessarily best for society. ${ }^{2}$

Conflicts between corporations and society over environmental issues almost always derive from private-social cost differences associated with pollution, the latter being the classic example of such differences. Some of the costs of an activity are externalized to the population as a whole through the spread of pollutants. Global warming, acid rain and pollution in cities are all examples of social costs exceeding private costs and consequent conflicts between corporate actors and society. Deforestation is another source of environmental conflict, again driven by differences in costs and benefits. To a landowner forests typically have economic value only as lumber and farmland, whereas to society at large they have recreational value, existence value, ${ }^{3}$ value in biodiversity support and value in carbon sequestration. So the social benefits of conservation exceed the private ones and society wants more conservation than firms find it profitable to provide.

Another source of corporate-societal conflict making headlines in recent years relates to the wages paid by rich-country firms in poor countries - the developing country sweatshop issue. These conflicts reflect the fact that markets produce outcomes that are efficient but not necessarily fair. The supply of and demand for labor in poor countries are such that $\$ 1$ per day is a market-clearing wage, yet when the product is sold for $\$ 100$ and more to people earning $\$ 50,000$, such a wage seems miserly in the extreme. ${ }^{4}$ The financial sector has also been accused of its share of unfair practices, usually involving discriminating against retail market participants either through insider trading or through unfair allocations at IPOs, or involving conflicts of interest at intermediaries.

One interpretation of several non-market systems that impinge on corporate behavior is that one of their objectives is to force corporations to internalize the private-social cost differences associated with these sources of conflict. Legal systems, regulators and non-governmental organizations can all be seen in this light - as systems that raise firms' awareness of the full social costs of their activities and pressure them to treat these as private costs.

\footnotetext{
${ }^{2}$ Francis Bator in a classic paper called these examples of "market failure." See Bator (1958).

${ }^{3}$ That is to say people value and are willing to pay for the existence of forests even if they personally make no use of them. Existence value is a major category of value for threatened species and for many wild places.

4 Although these wages are low, they may nevertheless be higher than those otherwise available to the employees - see Bhagwati (2004) and Harrison and Scorse (2003). See also Krugman (1999) http://slate.msn.com/id/56497/.
} 


\section{The role of CSR in environmental conflicts}

A CSR programme has a role to play in the conflicts just described. In the context of private-social cost differences, it can reduce the differences or compensate for them, and there are many examples of this being done at little or no cost. BP provides an illustration: in 1997 it took a stand on climate change, accepting the scientific evidence behind IPCC forecasts and acknowledging the appropriateness of reducing greenhouse gas emissions. BP imposed a firm-wide cap on greenhouse gas emissions and began a corporate emissions trading system. ${ }^{5}$ Emissions have been reduced significantly, ahead of schedule, and BP claims that this has not only cost nothing but has in fact increased net income by about $\$ 600$ million. Viewed from an economic perspective, what BP has done is to acknowledge that its operating costs - private costs - are less than the social costs of its activities and to take measures to bring the two into line. ${ }^{6}$ It has moved to reduce greenhouse gas emissions, something indicated to be appropriate by social costs but not by private. Dow Chemical presents a similar case: it responded to pressures to reduce pollution by systematically cutting back on all sources through which it could lose chemicals to the environment and in the process claims to have saved tens of millions of dollars of valuable solvents. ${ }^{7}$ Dow, like BP, has acted as if a social cost were a private cost. These companies have moved proactively to avoid conflict with society over environmental issues, conflicts which could have cost them greatly in terms of goodwill and brand equity, and in the process have also saved themselves significant amounts of money. Their investments paid them what in other contexts has been termed a "double dividend."

Heinz provides a third example of a company that profited from careful response to an environmental conflict, in this case over the killing of dolphins while fishing for tuna, a side effect causing the social costs of tuna fishing to exceed the private costs. The problem was that catching tuna often involved killing dolphins, and Heinz as a major seller of canned tuna was held responsible for this. ${ }^{8}$ Heinz chose to change their tuna sources from the eastern to the western pacific, where the dolphin by-catch is much less, and in the process become the dolphin-friendly tuna source. They incurred extra costs in doing this, but enhanced their brand and earned the congratulations of prominent politicians and environmentalists and avoided what would almost surely have been a costly and bruising confrontation. In terms of our economic model, they did what BP and Dow did: they brought their private costs into line with the greater social costs.

In these examples BP and Dow were able to make money by reducing pollution, which suggests that in fact they had miscalculated their private costs initially, and that pollution was rather surprisingly not the least expensive way of disposing of their wastes. How could this be? One contributing factor is that in some cases the costs of pollution, costs that were saved by ending pollution were opportunity costs. BP was flaring natural gas from some of its oil wells. There was no cash cost associated to this

\footnotetext{
${ }^{5}$ See Reinhardt (2000).

${ }^{6}$ See Reinhardt (2000).

${ }^{7}$ Heal (2000).

${ }^{8}$ Vietor and Reinhardt (1995).
} 
and so no line item in the accounts showing it as a cost, but there were revenues forgone as this gas could be collected and sold. Likewise with Dow, the loss of expensive reagents and products into the environment reduced the yield of its production processes in a way that was hard to see and not visible from its accounting data. So in these examples social costs did to some degree have private counterparts, but they were non-cash costs that were not visible from standard accounting perspectives. Many corporations may be missing non-cash private costs like these, and in the process overstating the differences between private and social costs and between the corporate and public interests, an accounting shortcoming that CSR policies can remedy. There may also be a strategic element to this overstatement: companies fear that by acknowledging costs they run the risk of being held responsible for them and so see it as in their interests to define their costs as narrowly as possible.

Other companies have done less well with CSR programmes, notable examples being Shell with the disposal of the Brent Spar oil buoy in the North $\mathrm{Sea}^{9}$ and McDonald's in a dispute about the use of polystyrene packaging for its products. ${ }^{10}$ Both, it seems, were trying to act responsibly and trying to take the high ground with respect to the environmental impacts of disposing of their waste, yet both emerged with damaged reputations from conflicts with environmental groups. Each made the mistake of formulating its own solution to the problem and pursuing this even though the environmental community believed that alternatives were preferable. The lesson here appears to be that it is not enough to have your own plan for reducing the conflicts with other groups in society: this plan has to be acceptable to them too - it takes two to avoid a conflict! A well-executed CSR programme not only will remove the conflict between a corporation and society, but will also document convincingly, perhaps through outside audits, that this has been done. This is reminiscent of the saying that it is not enough that justice is done - it must also be seen to be done.

Monsanto provides a complex example of a company destroyed by its failure to anticipate conflicts over possible private-social cost differences associated with the use of its products. Monsanto invested billions of dollars genetically modifying crops to make them more productive and require less use of insecticides, thus rendering the growing process less environmentally harmful. ${ }^{11}$ Their avowed aim was to make agriculture sustainable while improving crop yields in poor countries. ${ }^{12}$ With this aim and with proprietary technologies to implement it, Monsanto should have been a poster child for CSR, while instead they were destroyed by opposition from environmental groups. Consumer opposition to genetically modified crops led to their being abandoned by farmers, financially weakening Monsanto, which was then taken over. Monsanto's problem was that it focused on one private-social cost gap that associated with the use of insecticides on growing crops - but in the process missed another more serious one, that associated with people's fears of genetically

\footnotetext{
${ }^{9}$ See Baron (2003, p. 109).

${ }^{10}$ Livesey (1993).

${ }^{11}$ For background on Monsanto, see IMD (2003) and Watkins (2003). The investment advisory group Innovest has an interesting analyst's report on Monsanto on their web site. Go to www.innovestgroup.com then to "publications" then to "Monsanto and Genetic Engineering."

12 See Magretta (1997).
} 
modified foods. From the consumer perspective, Monsanto was seeking to raise farm productivity and lower farm pollution by passing to consumers new and unknown risks, namely the risks of food stuffs that had never been extensively tested. Monsanto's failure was not a failure to take CSR seriously, but a failure to implement it thoroughly and follow through on all of its implications.

\section{The role of CSR in distributional conflicts}

In Europe and the U.S. distributional issues have made headlines in the contexts of child labor in developing countries and low wages for adults in these same countries. Some of the earliest headlines were associated with the wages that Nike paid workers in its overseas factories, ${ }^{13}$ and with child labor in the rug industry in several developing countries. Here we have a different kind of issue from environmental conflicts. Market outcomes are efficient, ${ }^{14}$ but not necessarily fair according to widely held opinions on distributive justice. As poor countries often have massive quantities of unskilled or semi-skilled labor, and little in the way of industrial employment opportunities, industrial wages are very low, at the level of dollars per day with little or nothing in the way of benefits. While this may seem natural to an economist, there are many in rich countries to whom it seems outrageous that the people who make their shoes and clothes, which sell for $\$ 50-\$ 100$ or more, should receive such a small part of the revenues from their work in compensation. To complicate matters there is evidence that even at the low wages often offered by western companies, their employees are better off than they would be working for local firms, which often pay less, or than they would be without jobs, in which case they would usually have no social security system to provide support. ${ }^{15}$ Whatever the rights and wrongs of this situation, it is a source of controversy and discord, with attempts to organize boycotts of firms alleged to be paying unreasonably low wages to employees in poor countries. Nike was one of the first major corporations to face such a boycott, and it undoubtedly damaged its brand image.

Levi Strauss of the U.S. and Charles Veillon of Switzerland both faced the same issue and handled it more proactively. ${ }^{16}$ Levi moved before it became the target of criticism to ensure that working conditions and wages were reasonable all through its supply chain, and Veillon likewise moved proactively to ensure that they sourced rugs only from distributors who could guarantee that they met acceptable standards for child labor.

The lesson here is that there is indeed a role for CSR in distributional conflicts: a company with an active CSR policy will anticipate conflicts and act to minimize them before they flare up, as both Levi Strauss and Charles Veillon did. Nike, one of the first firms to become a centre of attention over fairness issues, failed to do this. They also did an initially unconvincing job of appointing outside auditors to verify the

\footnotetext{
${ }^{13}$ For background on the Nike case see Baron (2003, p. 113).

${ }^{14}$ Under the right circumstances - see any microeconomics text on this.

${ }^{15}$ See again Bhagwati (2004) and Harrison and Scorse (2003).

${ }^{16}$ See Reitz (2000) and for the Levi Strauss case see Baron (2003).
} 
changes in their policies. This is an important point: as we shall see below, it is often not enough to solve a problem. It has to be solved in a way that makes this point obvious even to skeptics, and invoking independent third parties is often critical here. It is interesting that Wal-Mart, the world's most successful retailer in terms of revenue and growth, is now the centre of frictions over similar distributional issues, but within the U.S. They are the defendants in a massive discrimination class-action suit and the target of hostile political actions because of their low wages and non-union policies. There is a real chance that this will limit their growth. All of these problems could clearly have been anticipated and to some degree avoided by a serious CSR policy devoted to anticipating conflicts and resolving them before they escalate. The financial sector has also been the scene of distributional debates, as already mentioned, and I return to these later.

\section{Defining CSR}

The issues raised provide us with an implicit definition of CSR, which we now formalize. CSR involves taking actions which reduce the extent of externalized costs or avoid distributional conflicts. This is different from other definitions that have been offered: the European Union defines CSR as a programme in which "companies decide voluntarily to contribute to a better society and a cleaner environment."17 Hopkins in an International Labor Organization discussion paper states that "CSR is concerned with treating stakeholders of the firm ethically or in a responsible manner." 18 The OECD comes nearest to the definition that I have just suggested, commenting that "the common aim of the governments adhering to the Guidelines (OECD guidelines to multinational enterprises on corporate responsibility) is to encourage the positive contributions that multinational enterprises can make to economics, environmental and social progress and to minimize the difficulties to which their various operations may give rise (italics added)." ${ }^{19}$ This is clearly seeing CSR as a move to increase the social value added by corporate activity. Beltratti ${ }^{20}$ makes an interesting comment that CSR is "an attempt to escape profit maximization in the recognition that agency problems and incomplete contracts undermine the basic idea of shareholders' supremacy." There is a sense in which my definition draws on the tradition established by Ronald Coase in his paper "The Problem of Social Cost." In cases where costs are externalized, corporations bargain with society about who will ultimately bear these costs. The corporation is not - currently - legally bound to bear them but society could change this if it wished, and indeed could go further and impose penalties for the past externalization of costs. The result is an implicit contract: society accepts the legal status quo provided that the corporation does not exploit it to society's disadvantage.

\footnotetext{
${ }^{17}$ Quoted in Beltratti (2004).

18 Hopkins (2004).

${ }^{19}$ OECD (2003).

${ }^{20}$ Beltratti (2004).
} 
This analysis of CSR differs from that of Friedman, ${ }^{21}$ though it is not in conflict with it. Friedman states that the responsibilities of corporate managers are to obey the law, abide by generally accepted ethical principles and maximize returns to shareholders. He assumes that the government has taken care of distributional issues and has defined property rights so that there are no external effects, no private-social cost differences. Within this context he argues that there is no role for CSR: profit maximization, doing what is best for shareholders, is also best for society. In saying this he is just invoking Adam Smith's dictum about the invisible hand. In this context, policies that benefit outside interest groups and shareholders are not CSR but merely profit maximization, and policies that benefit outside groups and not shareholders are theft from shareholders and a violation of managers' obligations to their employers. They are also not efficient for society as a whole. I do not differ from this, but instead address the more realistic case that Friedman assumes away in which the government has not resolved problems with external effects and distributional conflicts. In this case the invisible hand needs some help, as competitive markets are not efficient. What I add to Friedman's analysis is that in this case, which describes better than his the world around us, CSR policies have a natural role to play, a role that benefits shareholders and other stakeholders. We can think of this role as substituting for missing markets, if we see external effects as arising from missing markets, or as taking what Friedman sees as the government's place in addressing external effects and distributional issues.

\section{CSR and financial performance}

We have defined a role for CSR policies based on economic fundamentals. The role is to anticipate and minimize conflicts between corporations and society and its representatives, aligning private and social costs if differences are the source of the conflict, or minimizing distributional conflicts if these are the issue. The literature on CSR suggests that the avoidance or reduction of conflicts is indeed a major contribution of effective corporate CSR programmes. A comprehensive list of the benefits that commentators have linked to CSR programmes includes the following:

(1) Reducing risk

(2) Reduced waste

(3) Improving relations with regulators

(4) Generating brand equity

(5) Improved human relations and employee productivity

(6) Lower cost of capital

\section{Risk management}

The first of these has already been discussed and needs little elaboration at this stage, except to emphasize that the cost of conflicts with other groups in society, especially

\footnotetext{
${ }^{21}$ Friedman (1971).
} 
aggressive non-governmental organizations (NGOs), can be very high, as the Nike, McDonald's, Monsanto and Shell cases demonstrate. Such conflicts can depress earnings and share prices and give competitors an opportunity to seize market share.

\section{Waste reduction}

The second benefit, reduction of waste, we have also mentioned before in the context of BP's reduction in greenhouse gas emissions and Dow's reduction in the loss of organic chemicals to the environment. It is a recurring theme in studies of the benefits from CSR, and suggests that many companies are just not seeing the savings available from better management of materials and processes, perhaps because these in many cases are non-cash costs.

\section{Regulatory protection}

A corporation's relationship with regulators can be of real significance in heavily regulated industries. BP appears to have had considerable influence on the greenhouse gas policies adopted by the European Union, playing a role in persuading the EU to meet its obligations under the Kyoto Protocol by an emission trading system similar to that which BP has adopted for its own internal use. A reputation for being "green" can also be of use to an oil company in negotiations for access to potential oil reserves in environmentally sensitive areas, such as the forests of central and South America or the Caspian Sea. Applications for exploration permits in such areas are generally contested by environmental groups, and a reputation for environmental sensitivity may be an asset in overcoming the reservations raised. In general, a regulatory decision in favor of a company with a strong reputation for socially responsible behavior will be greeted more positively than one in favor of a company seen as antisocial in its conduct, and this must influence regulators in their decisions. ${ }^{22}$

\section{Brand equity}

An elusive but nevertheless critical concept for many modern corporations is "branding". With strong competition and little in terms of technology differentiating the available products, a product's "buzz" or image can be critical in tipping customers' decisions, and this is often the product of ephemeral fads and fashions that are easily destabilized. Nike's market momentum dropped off when the low wages paid to its developing country employees were publicized, and Shell suffered a loss of sales in Europe at the time of the dispute over its disposal of the Brent Spar oil buoy. Starbucks, in a competitive and image-conscious market, has found it worthwhile to invest in avoiding conflicts that could damage its reputation, and in publicizing its links with Conservation International. Specifically, Starbucks has made a substantial investment in sourcing coffee from growers with an environmentally friendly profile,

\footnotetext{
${ }^{22}$ At the time of writing there is evidence that the President of Merck and Co. was given credit for Merck's sterling reputation as a responsible company (see the section on Pharmaceuticals and CSR) at recent U.S. Congressional hearings on the withdrawal of Vioxx.
} 
in association with the NGO Conservation International, and has recently agreed to purchase coffee through the Fair Trade NGO, which guarantees that the prices paid to growers are in excess of world prices and provide a reasonable living standard. ${ }^{23}$ Starbucks is therefore taking preemptive action on both the possible sources of conflict with society - environmental degradation and fair treatment of the low paid. ${ }^{24}$ There is evidence that consumers are sensitive to companies' positions on CSR and react to these in their purchasing decisions. Starbucks' hope is that consumers will discriminate in favor of the responsible trader, or at least against those who do not make their credentials in this area clear. All of these effects are summarized by saying that CSR policies affect the value of a company's brand. Product certification systems are a method of enhancing and channelling this consumer awareness by associating a certification brand with products that meet appropriate standards. The Forest Stewardship Council, the Marine Stewardship Council, Fair Trade and others are all organizations that are seeking to raise consumer sensitivity to the social or environmental dimensions of a product and then associate positive performance on those dimensions with a particular logo, for which the seller typically has to pay a commission. ${ }^{25}$ The Forest Stewardship Council (FSC) is typical of these operations, and certifies wood as having been produced in an environmentally friendly manner, charging the producers of this wood for the certification. The hope here is that consumers will discriminate in favor of certified wood products, or against those not so certified, justifying the cost of certification for the producers.

\section{Employee productivity}

There are several aspects to the impact of CSR on a firm's relationship with its employees. One aspect of this is that people seek to work for "good" companies, companies they can be proud of. They do not like having to justify or excuse their companies to their friends and families, and as a result companies with a good CSR record have more success recruiting, maintaining and motivating employees than companies with a poor record. A survey of MBAs' attitudes towards potential employers emphasizes this point, noting that they are willing to take lower pay in order to work for companies that have a more positive social image. ${ }^{26}$ Roy Vagelos, ex-Chief Executive and Chairman of Merck, tells a story that reinforces this point. ${ }^{27}$ In the late 1980s and 1990s Merck developed a drug that cured river blindness, a painful disease that afflicted millions in tropical Africa, eventually leaving them blind. None of the victims could afford to pay for the drug, and after failing to get the U.S.

\footnotetext{
${ }^{23}$ Over the last few years there has been a glut of coffee and world market prices have fallen reducing the living standards of coffee farmers in poor countries. Fair Trade seeks to ensure that a larger-than-normal fraction of the sale price of the coffee beans goes to the farmers.

${ }^{24}$ For details see Austin and Reavis (2003).

${ }^{25}$ For more on certification see Conroy (2001).

${ }^{26}$ See Montgomery and Ramus 2003

${ }^{27}$ See The Business Enterprise Trust (1991). This discussion also draws on personal communications with Dr. Vagelos and remarks made by him at Columbia Business School on 25 August 2004. See also Vagelos and Galambos (2004).
} 
government and the World Health Organization to pay for the medicine at cost, Merck eventually made the decision to supply and distribute it to all affected populations free of charge, and by 2003 it had treated about 30 million people through this programme. The cash cost to Merck was considerable, however, Vagelos believes that Merck's River Blindness programme enabled it to recruit very able scientists who would not otherwise have been available and thus contributed to its human and intellectual capital.

Another aspect of the relationship between CSR and employee management works through what economists have called the "efficiency wage theory." The central premise here is that employees work harder if they are paid more, so productivity can be raised by paying more than the minimum needed to fill jobs, and consequently paying more than the market wage may help profits by boosting output by more than it boosts costs. This insight is not a new one, but goes back to the 19th century, as The Economist has noted: ${ }^{28}$

The notorious "robber barons" built much of America's educational and health infrastructure. Company towns, such as Pullman, were constructed, the argument being that well-housed, well-educated workers would be more productive than their feckless, slum-dwelling contemporaries.

Companies introduced pensions and health-care benefits long before governments told them to do so. Procter \& Gamble pioneered disability and retirement pensions (in 1915), the eight-hour day (in 1918) and, most important of all, guaranteed work for at least 48 weeks a year (in the 1920 s). Henry Ford became a cult figure by paying his workers $\$ 5$ an hour - twice the market rate. Henry Heinz paid for education in citizenship for his employees, and Tom Watson's IBM gave its workers everything from subsidised education to country-club membership."

So it can be in a company's interest to pay more than is strictly necessary to retain its labor force, and this can both contribute to its bottom line and develop a reputation for being a good employer and being socially responsible.

\section{Cost of capital}

CSR may reduce a company's cost of capital through the impact of CSR's financial cousin, Socially Responsible Investment (SRI). A growing movement, SRI now accounts for in the order of 12 per cent of funds under professional management in the U.S. and a smaller but growing fraction in European countries. SRI funds are invested with restrictions on the shares that can be purchased. These may be simple bans on alcohol and tobacco or more sophisticated rules that invest preferentially in firms receiving high ratings for their social and environmental performance from agencies such as Innovest, which evaluates corporations according to their attitude towards the environment, employment of minorities, treatment of employees in low-wage countries

\footnotetext{
${ }^{28}$ The Economist (2003).
} 
and other related issues. ${ }^{29} \mathrm{~A}$ sophisticated SRI fund allocates its investments by sector in much the same way as a conventional fund, but within each sector is guided by social and environmental ratings as well as by the financial characteristics of companies. If significant sums of money are invested preferentially in companies with good CSR records, their cost of capital will fall. There is currently no evidence that this is a major effect, and indeed the impact of CSR programmes on financial performance is a complex and controversial issue to which I turn next.

\section{CSR and capital markets}

The growth of SRI suggests there may be a connection between a firm's policies towards CSR and its position in capital markets. At the same time, one of the tenets of CSR proponents is that it raises profits in the long run, through the six mechanisms outlined in the previous section, making CSR companies more attractive to investors. This suggests another connection between CSR programmes and capital market performance.

\section{CSR and stock market value}

One of the first papers to illuminate the connection between CSR and capital markets was Hamilton's 1995 study of the announcement of toxic releases inventory (TRI) data. ${ }^{30}$ In the TRI, the U.S. Environmental Protection Agency (EPA) makes public firms' self-assessed releases of toxic chemicals. Hamilton looked at the treatment of these announcements by the press and also at their impact on share prices. He used event study methodology to identify how the announcement of toxic releases affected the stock market values of the releasing firms relative to the market as a whole. The first TRI data to be released was for 1989, and it is this release that Hamilton studies. He finds a significant negative impact of releases on stock prices, with an average impact on releasing firms' stock market values of $\$ 4.1$ million. The size of the impact depends on the number of chemicals released by the firm, increasing by $\$ 236,000$ for each additional chemical.

An interesting aspect of these results is that the release of toxic chemicals is a negative externality imposed on the rest of society, clear evidence of social costs in excess of private costs, and capital markets are penalizing this. There is therefore a reason to believe that reducing the excess of social over private costs - as in the cases of BP and Dow - may raise stock market value and reward shareholders.

Several subsequent studies have found similar results for other countries. Dasgupta et $a l^{31}$ studied the way in which capital markets in Argentina, Chile, Mexico and the Philippines reacted to information about a firm's environmental performance. Their raw data were public recognition of firms' superior or inferior environmental performances, drawn from articles in major business newspapers addressing corporate

\footnotetext{
${ }^{29}$ See www.innovestgroup.com.

${ }^{30}$ Hamilton (1995)

${ }^{31}$ Dasgupta et al. (2001)
} 
environmental performance. Superior environmental performance was defined as recognition by a regulator or other government authority that a firm met or exceeded expected standards, and inferior performance was defined as the filing of a complaint against a firm, by a regulator or by a member of the public. All cases of superior or inferior performance were analyzed using event study methods. In the case of recognition of superior performance, the average rise in stock market value was 20 per cent, and in cases of poor performance the drop in value ranged from 5 per cent to 15 per cent. A later study by Dasgupta et $a l .^{32}$ found similar results for The Republic of Korea. The Korean Ministry of the Environment has for many years published monthly a list of firms that fail to comply with the country's environmental laws, called the Monthly Violations Report. Again using event study methodology these authors showed that featuring on this list on average caused a company's stock price to drop by 9.7 per cent.

What is interesting about all of these event studies is that they find a link between the release of information that a firm's social costs exceed its private costs and the change in the stock market value of the firm. In these cases, capital markets are clearly penalizing firms whose social costs exceed their private costs. Precisely why they do this is not clear from the studies: presumably capital markets are anticipating that firms will at some point be forced to pay for the excess of private over social costs, or at least for some part of this. They are therefore treating this excess, or some part of it, as a liability to the firm. Another salient aspect of these studies is that it is rather clear which way causation runs - rather clear that the release of information about pollution causes stock prices to change rather than vice versa. This may seem so obvious as to be barely worth mention, but assumes significance given the fact that many other studies find correlations between environmental ratings and financial performance but are unable to determine the direction of causation. This remark applies to all the studies reviewed in the remainder of this section.

Dowell, Hart and Yeung (DHY) ${ }^{33}$ examined this issue from a rather different perspective. Measuring Tobin's q, the ratio of the stock market value of the company to the cost of its tangible assets, they found a positive correlation between this and environmental performance. Their study is restricted to U.S. manufacturing companies in the S\&P 500 operating in the U.S. and in middle-income countries. These firms were divided into three categories: (1) those that operate at U.S. environmental standards worldwide even if this involves exceeding legally required standards outside the U.S., (2) those that operate a uniform worldwide standard above that required in the U.S., and (3) those that adopt standards lower than the U.S. where this is permitted. Clearly the second group has the highest environmental standards, the first group has the next highest and the third group has the lowest. It is this measure of environmental performance - membership of groups (2), (1) or (3) that DHY find to be correlated with the ratio of stock market value to the cost of tangible assets.

\footnotetext{
${ }^{32}$ Dasgupta et al. (2004).

33 Dowell et al. (2000).
} 
The DHY study was pioneering and has justly been the focus of much attention. There are nevertheless many questions about what exactly it establishes. To mention just a few, Tobin's q is not the only or indeed the most obvious measure of financial success: returns on assets or on equity are alternative measures. In calculating Tobin's $\mathrm{q}$, the cost of tangible assets is found by summing the book value of inventory and the net value of physical plant and equipment. Book values are rarely good guides to market values and the value of plant and equipment net of depreciation is heavily influenced by depreciation policies. Environmental performance is self-reported and is not independently audited. Finally, there is the standard comment that correlation does not imply causation, so that the correlation between Tobin's q and environmental performance could arise from one or more other factors that are causing both. In spite of these limitations the DHY paper raises interesting questions and is a step forward in connecting one aspect of CSR with capital markets and financial performance. One particularly thought-provoking comment by the authors is that capital market valuations internalize externalities, that is, the capital markets recognize difference between private and social costs and treat the excess of social over private as a liability that the corporation will have to meet at some point. ${ }^{34}$ This is entirely consistent with the definition of and motivation for CSR that I am advancing.

King and Lennox ${ }^{35}$ conducted a related study, concluding that

We find evidence of a real association between lower pollution and higher financial performance. We also show that a firm's environmental performance relative to its industry is associated with higher financial performance. We cannot show conclusively, however, that a firm's choice to operate in cleaner industries is associated with better financial performance, nor can we prove the causal direction of the observed relationships. Thus, our research provides support for a connection between some means of pollution reduction and financial performance, but it also suggests that the reason for this connection remains to be established.

These findings are consistent with those of DHY, indicating from a different and larger sample of firms that there is a correlation between environmental performance (now measured by the quantity of emissions) and Tobin's q, but again failing to clarify unambiguously the nature of the causation at work and the reasons for this correlation. We can take it from these two studies that the correlation is well established, but not well explained. Hence the importance of the event studies by Hamilton and his successors, which as emphasized earlier do give an unambiguous statement that causation runs from environmental performance to stock prices.

\footnotetext{
${ }^{34}$ Interestingly, this is exactly how financial analysts assessed the appropriateness of the drop in Merck's share price after the withdrawal of Vioxx - they calculated the loss of profits and then also the legal liability to which Merck was exposed because of the costs possibly imposed on the users of its product Vioxx.

${ }^{35}$ King and Lennox (2001).
} 


\section{CSR, SRI and portfolio management}

Geczy et $a{ }^{36}{ }^{36}$ tackled a different aspect of this nexus, looking at the performance of SRI mutual funds and, in keeping with the positions taken by many in the finance profession, argued that SRI funds must always underperform funds that are not constrained by ethical considerations and that the only open question is the extent of the underperformance. Their claim is that for index funds this underperformance is marginal, whereas for funds with a particular investment style - such as small-cap growth for example - it may be as high as 3.7 per cent per year. This argument does not in any way depend on the financial performance of companies with active CSR programme, but is rooted in some very basic aspects of one of the widely used models of financial markets. Their argument is that by restricting the universe from which stocks can be picked, a fund manager cannot improve his performance and may worsen it. If the investment problem is posed as one of selecting a portfolio from a universe of stocks whose stochastic properties are known, or learned from observation as time passes, then this argument is incontrovertible. Information about CSR profiles can add nothing, and this set of assumptions is consistent with the Capital Asset Pricing Model, one of the frameworks most widely used in finance.

There are, however, alternatives, and it is on these that SRI managers base their claims that SRI funds can outperform others. Specifically the SRI claim, articulated among others by Innovest on their web site, is that the stochastic properties of stock prices are unknown and that being aware of CSR programmes adds information that is not otherwise available to investors. It tells investors, for example, that management in a textile company is well prepared to handle questions about their employees in poor countries and so not likely to be the subject of a boycott, and that executives of an oil company understand and have thought about the environmental impacts of their operation and will be able to deal with criticism from NGOs. This information also tells investors that any benefits from cleaner production, as reaped by BP and Dow, are already being harvested. This, it is argued, is valuable information for investors and is not duplicated by standard data about financial characteristics and market performance. So attention to CSR policies gives an additional dimension of information to analysts, potentially allowing them a different perspective on corporate prospects. Consistent with this is a recent statement by Standard and Poor's, which states that it now recognizes "the growing importance of non-financial disclosure in the overall assessment of a company's risk profile." 37

Unfortunately, the data on the performance of SRI funds relative to the rest of the fund universe, which should in principle resolve this issue, is ambiguous. Some SRI funds have outperformed the market consistently - but perhaps this just reflects the skill of the managers and not the merits of their investment philosophy. A recent study by Bauer et al. ${ }^{38}$ suggests that in the U.K. SRI funds have slightly outperformed their non-SRI competitors, whereas in the U.S. the opposite was true in the first 5-10 years

\footnotetext{
${ }^{36}$ Geczy et al. (2003).

37 The Economist (2004).

${ }^{38}$ http://www.socialinvest.org/areas/research/Moskowitz/2002_full.pdf
} 
studied, with a slight outperformance again emerging in the last half of the decade 1990-2001. Some idea of the complexity of these issues is provided by the performance of SRI funds in the U.S. over the period 1995-2000: over this period several SRI funds clearly outperformed the standard benchmark indices. However, was this because they were SRI funds or is there another reason? Because of the managers' emphasis on avoiding companies that pollute or are involved in arms manufacture, tobacco or alcohol, the portfolios of SRI funds were overweighted, relative to the standard indices, in stock such as Microsoft, Intel and Cisco, all of which are relatively untainted by environmental or social ills. ${ }^{39}$ These are precisely the stocks that showed spectacular growth from the mid-1990s to the end of the century, so that the performance of SRI funds could be explained by their being overweight in growth stocks. This does not provide a basis for expecting continued superior performance by these funds.

Innovest take an interesting approach to the evaluation of SRI portfolios. They look at standard portfolios for specific investment styles, and then ask the following question: What would happen, or would have happened, if the stocks in a particular portfolio had been replaced by similar stock (same sector, same financial characteristics) but with higher CSR rating? They then track both portfolios, and find almost universally that the modified portfolio beats the original. Their idea is not to construct an "SRI portfolio" but rather to modify an existing portfolio - be it growth or value or tech - to achieve a higher CSR rating overall and then compare the performance of the two. Neither is an SRI portfolio - one is, for example, a small-cap portfolio and the other a small-cap portfolio modified to retain most of its statistical characteristics but yet attain higher CSR ratings. ${ }^{40}$ Consistent with these findings is the observation that, when firms in a sector are divided into high and low-ranked on environmental criteria, those in the high-ranked group usually perform better financially than those that are low-rated.

What conclusions can we take away from the literature on CSR, SRI and capital markets? One robust result seems to be that superior environmental performance is correlated with high values for Tobin's q. This suggests that CSR pays, but does not prove it. Another robust conclusion seems to be that SRI funds do not systematically underperform their non-SRI competitors, suggesting that if there are costs - as opposed to benefits - from CSR programmes, then they must be small. A more tentative result is that SRI funds may have a small performance edge over their competitors, but this is a more speculative statement, particularly as the performance data are dominated by the 1990s and SRI funds were heavily overweighted in high-performing growth stocks over this period. Also tentative is the conclusion that considering CSR information can improve the performance of a portfolio of any type.

\footnotetext{
${ }^{39}$ There are issues related to the use of poisonous chemicals in chip making and to the disposal of unused electronic equipment, but these are so far small relative to the environmental impacts of many other industries.

${ }^{40}$ www.innovestgroup.com
} 


\section{Financial institutions and CSR}

For financial institutions the private and social costs of operations are usually similar, implying that for the financial sector external effects are not typically a source of conflict with society, although for the clients whose operations these institutions facilitate this is often not the case, a point to which we return below. There are however many cases in which there are distributional conflicts generated by the financial sector. To deal with the simplest first, currently several large U.K. and U.S. investment banks are the targets of lawsuits alleging gender discrimination and sexual harassment, and the abundance of such suits in the investment banking industry for a decade or more suggests that they could clearly benefit from applying some of the most elementary ideas of CSR to their own human resources policies.

Investment banks and insurance companies have been accused, and indeed found guilty, of other forms of inequity, most of which arise from unfair treatment of some of their clients. Insider trading, common in many financial markets, is an example. People with privileged access to financial information (not always but often in financial institutions) exploit this at the expense of their clients and the trading public in general. At the heart of arguments about insider trading is a conflict about the fair or proper distribution of the gains from participation in financial markets. Recent U.S. cases concerning the allocation of shares in initial public offerings (IPOs) are of the same type: the allegations here were that brokers issued undervalued shares to people who would bring them additional business although they purported to issue them in a manner giving equal access to all potential buyers. Again, the issue is the distribution of the benefits from market participation. Fake bids, rigged auctions and volume-contingent commissions in the insurance industry are also of this genre moves by brokers to appropriate for themselves that which is commonly considered due to others. So while financial institutions are not normally sources of private-social cost conflicts through their own actions, they clearly can be and often are sources of acute distributional conflicts through their control over access to the gains from trading in financial markets.

A different set of issue arises when we look at the operations of banks' clients, operations that are often financed by the banks. Did Nike's banks finance sweatshops? Do Exxon's banks finance environmental degradation? Banks are vulnerable to charges of socially inappropriate behavior through the actions of their clients, for which the banks are sometimes held responsible on the grounds that without their knowledge and financial support these actions would not occur. This explains the Equator Principles, which were agreed to by 10 major banks in June of 2003, and are now agreed to by a total of $25 .^{41}$ The Equator Principles are a set of principles committing the signatory banks to finance only projects that meet social responsibility criteria - the founding declaration states:

In adopting the Equator Principles, a bank undertakes to provide loans only to those projects whose sponsors can demonstrate to the satisfaction of the bank their ability and willingness to comply with comprehensive processes aimed at

\footnotetext{
${ }^{41}$ For a list see http://www.equator-principles.com/.
} 
ensuring that projects are developed in a socially responsible manner and according to sound environmental management practices.

The Equator Principles will use a screening process for projects which is based on IFC' $\mathrm{s}^{42}$ environmental and social screening process. Projects will be categorized as $\mathrm{A}, \mathrm{B}$ or $\mathrm{C}$ (high, medium or low environmental or social risk) by the banks, using common terminology. For A and B projects (high and medium risk), the borrower will complete an Environmental Assessment addressing the environmental and social issues identified in the categorization process. After appropriate consultation with affected local stakeholders, category A projects, and category $\mathrm{B}$ projects where appropriate, will prepare Environmental Management Plans which address mitigation and monitoring of environmental and social risks.

The Environmental Assessment will address such issues as:

- Sustainable development and use of renewable natural resources.

- Protection of human health, cultural properties, and biodiversity, including endangered species and sensitive ecosystems.

- Use of dangerous substances.

- Major hazards.

- Occupational health and safety.

- Fire prevention and life safety.

- Socioeconomic impacts.

- Land acquisition and land use.

- Involuntary resettlement.

- Impacts on indigenous peoples and communities.

- Cumulative impacts of existing projects, the proposed project and anticipated future projects.

- Participation of affected parties in the design, review and implementation of the project.

- Consideration of environmentally and socially preferable alternatives.

- Efficient production, delivery and use of energy.

- Pollution prevention and waste minimization, pollution controls (liquid effluents and air emissions) and solid and chemical waste management.

The borrower will be required to demonstrate to the bank that the project complies with host country laws and the World Bank and IFC Pollution Prevention and Abatement Guidelines for the relevant industry sector. For projects in the emerging markets, the borrower would also have to demonstrate that the Environmental Assessment has taken into account the IFC Safeguard Polices, which provide guidance on issues such as natural habitats, indigenous peoples, involuntary resettlement, safety of dams, forestry, and cultural property.

\footnotetext{
${ }^{42}$ International Finance Corporation.
} 
This statement makes it very clear that the aims of the Equator Principles are to ensure that major loans (more than $\$ 50$ million) by banks are made to clients who meet CSR criteria, in the process ensuring that banks are not in a position where society can hold them responsible for environmental damage or for outcomes that violate basic concepts of fairness. Not only does this prevent banks from being held responsible for antisocial use of their funds, it also makes good business sense for the banks. It means that they avoid lending on controversial projects, and controversial projects are those that are likely to be unprofitable, or less profitable than expected, because of governmental interventions to support the social interest. These are precisely the projects where borrowers may have difficulty in repaying the loans, so the Equator Principles should be good for the bottom lines of the signatory banks, as well as good for society as a whole. What we have here is CSR as a form of risk management for banks. Recent comments by Chris Beale, Head of Project Finance at Citigroup, emphasize this point:

Well defined environmental and social policies, such as EP (Equator Principles), clearly make it less likely that we will find ourselves in trouble in the future, but there is no historical cost that we can quantify. We could take a view on default risk in the future but this too is difficult to measure. However, EP presents a framework for business risk reduction, primarily more quantifiable as reputational risk... Banks face both credit and reputation risk when they finance development around the world. If sponsors adopt and follow EP for sensitive projects, they might well enjoy a faster implementation period, with the end result being that the project starts generating revenue streams earlier, avoiding the specter of costly interruptions, delays and retrenchments.

The belief is, he says, that "EP will lead to more secure investments on the part of customers and safer loans on the part of banks." Mr. Beale implies that the downside to not paying heed to EP concerns could be disastrous: "If banks finance something dirty or that harms people, it's possible the host government or local people will interfere with or even confiscate the private development project."43

\section{Pharmaceuticals and CSR}

There are some similarities between the financial and pharmaceutical sectors as far as CSR is concerned. Neither is the target of accusations of environmental degradation. Indeed the pharmaceutical industry has on occasions been a favorite of environmentalists because its use of bioprospecting has seemed to give an economic justification and economic value to the conservation of biodiversity. Merck made a pioneering deal with Inbio of Costa Rica to fund the conservation of biodiversity in exchange for access to pharmacologically interesting specimens, and Shaman

\footnotetext{
${ }^{43}$ Quoted from Greenfield (2004).
} 
Pharmaceuticals attempted to build a drug-discovery business on the knowledge that traditional healers have of the properties of plant and insect extracts from tropical regions. In 1999 the pharmaceutical multinational Glaxo Wellcome (now a part of GlaxoSmithKline) and a small Brazilian biotechnology company signed a \$3.2-million contract to screen up to 30,000 compounds of plant, fungal and bacterial origin from several regions in Brazil. As part of the 3-year deal, the companies agreed that onequarter of any royalties arising from successfully exploited patents will be used to support community-based conservation, health and education projects. Another 25 per cent of the royalties will go to the university group responsible for isolating and identifying the product. Glaxo Wellcome will pay for all research and development costs in Brazil. The research will focus on compounds found in the Amazonian and Atlantic rainforests, and Glaxo Wellcome will have an option to license any product arising from it. In addition to its funding of environmental conservation, Merck made CSR history with its decision to fund the development and provision of drugs for river blindness, as discussed in the section on CSR and financial performance.

In spite of an encouraging track record, the pharmaceutical industry is now held in low public esteem and is a centre of political conflict. The first factors to contribute to this were the pricing of AIDS drugs in poor countries and drug pricing policies in the U.S. market, and the negative aura stemming from these was reinforced by debates about the safety of some blockbuster drugs and allegations that the industry puts profits before customer safety. The pricing of AIDS drugs created a classic distributional discord about the treatment of poor people and damaged the reputation of pharmaceutical companies, for very little in the way of financial gains. And the way pricing in the U.S. is being managed is also creating a distributional debate as those most severely affected by company pricing policies are the poor and the elderly, to whom the pharmaceutical companies are appearing insensitive. The risk that they run from this behavior is the withdrawal of public support for the system that allows them to charge higher prices in the U.S. than elsewhere and fund their R\&D disproportionately from this. They are creating an atmosphere that could be conducive to more extensive government involvement in pricing in the U.S., something that they surely do not want.

The debate about profits vs. safety came to a head with the withdrawal of Vioxx, a best-selling pain reliever produced by Merck. This was accompanied by allegations that risks associated with the drug had been known for some time before Merck acted, and that these were suppressed or discredited to allow continuing sales. However, the withdrawal of Vioxx did not occur in isolation: it came after the publication of a book severely critical of the pharmaceutical industry's priorities ${ }^{44}$ and mode of operation, and the withdrawal of Bayer's Baycol cholesterol-reduction drug again amidst allegations that it should have been removed from the market earlier. Vioxx's withdrawal also prompted comments that other widely used drugs posed risks to consumers that were not adequately appreciated.

Allegations that pharmaceutical companies put profits before safety can be interpreted in two ways in the framework presented so far. There is a distributional

\footnotetext{
44 Angel (2004).
} 
aspect: shareholders are being favored at the expense of customers, indeed customers are being exploited for the benefit of shareholders. However, there is also a difference between the private and social benefits, with the benefits from drug sales to the companies exceeding those to the customers. A cost is imposed on the customers, the risk of serious illness as a side effect of drug use. It is clear that safety concerns about their products impose very major costs on pharmaceutical companies. The following is an analysis of the impact the Vioxx problem on Merck's stock market valuation: ${ }^{45}$

The required amount of litigation reserve implied by Monday's closing stock price appears to be around \$25 billion. We calculate this amount by subtracting two components from MRK's market cap reduction since the Vioxx withdrawal: the $\mathrm{NPV}^{46}$ of the COX $-2^{47}$ franchise and the reduction in the industry's market cap since the Vioxx withdrawal. MRK's closing price the day before the Vioxx withdrawal (29 September 2004) was \$45.07, indicating a market cap of \$102 billion. We estimate the NPV of lost Vioxx and Arcoxia revenues to be approximately $\$ 16$ billion, assuming 5 per cent COGS, ${ }^{48}$ a 10 per cent SG\&A benefit, a 7 per cent discount rate, and a 28.5 per cent tax rate. In addition, the industry market cap (excluding MRK) has fallen by approximately 3 per cent since September 29, implying a \$3 billion reduction to MRK's market cap. Based on Monday's closing price, MRK's market cap was about $\$ 58$ billion, which implies that the market is estimating required Vioxx litigation reserves to be around \$25 billion.

We estimated an extreme case total liability scenario for MRK using the Kaiser Permanente total number of acute $\mathrm{MI}^{49}$ and sudden cardiac death plaintiffs esimate of 27,785 ( www.fda.gov/cder/drug/infopage/vioxx/vioxxgraham.pdf) and one lawyer's estimate that each of these cases could be worth $\$ 1$ million. Accordingly, it appears this extreme case scenario could be $\$ 27.8$ billion in total Vioxx liability for MRK, based on this "back of the envelope" calculation. It is important to note the limitations of this calculation: more than 28,000 suits may be filed; it is unlikely that all plaintiffs will win their case; $\$ 1$ million for each case may not be entirely accurate. To take this already aggressive analysis a step further, we can assume that an additional 25,000 less robust claims will be filed and that MRK will pay these plaintiffs $\$ 100,000 /$ claim, resulting in an additional $\$ 2.5$ billion in potential liabilities, for a total extreme scenario estimate of about $\$ 30$ billion.

The point to note about this analysis is that it clearly indicates that the stock market has valued the liabilities that Merck incurred as a result of imposing external costs on customers, consistent with the suggestion by Dowell, Hart and Yeung that capital

\footnotetext{
${ }^{45}$ From www.smithbarney.com, posted on 9 November 2004, viewed on 30 November 2004 and written by George Grofik CFA and Eric Trepanier Pharm. D.

${ }^{46}$ Net present value, the current money equivalent of the revenue stream from Merck's COX-2 products.

${ }^{47}$ Vioxx is a COX-2 inhibitor.

${ }^{48} \mathrm{COGS}=$ cost of goods sold, $\mathrm{SG} \& \mathrm{~A}=$ sales general and administrative costs.

${ }^{49}$ Myocardial infarction, or heart attack.
} 
markets regard external costs as liabilities to be charged against a corporation's stock market value. Another interesting point is that the Smith Barney analysts value the loss of profits from Vioxx at $\$ 16$ billion, whereas the total costs to Merck are estimated at this plus another \$25-30 billion. So Vioxx was a very significant net drain on the resources of Merck's shareholders: early action would have saved them of the order of $\$ 30$ billion. It appears that "Big Pharma" could certainly have benefited from a wellconstructed programme in CSR over the last 10 years.

\section{Conclusions}

We can tell an economically coherent story about CSR, and use financial markets to validate it. The story suggests that there is a resource-allocation role for CSR programmes in cases of market failure through private-social cost differentials, and also in cases where distributional disagreements are likely to be strong. In some sectors of the economy private and social costs are roughly in line and distributional debates are unusual: here CSR has little role to play. Such sectors are outnumbered by those where CSR can play a valuable role in ensuring that the invisible hand acts, as intended, to produce the social good. In addition, it seems clear that a CSR programme can be a profitable element of corporate strategy, contributing to risk management and to the maintenance of relationships that are important to long-term profitability.

\section{References}

Angel, M. (2004) The Truth About the Drug Companies: How They Deceive Us and What to Do About It, New York: Random House.

Austin, J.E. and Reavis, C. (2003) 'Harvard Business School case "Starbucks and Conservation International", Case 9-303-055, Boston, MA: Harvard Business School Publishing.

Baron, D.P. (2003) Business and Its Environment, 4th Edition, Upper Saddle River, NJ: Prentice-Hall.

Bator, F.M. (1958) 'Anatomy of market failure', The Quarterly Journal of Economics 72: 351-379.

Beltratti, A. (2004) The complementarity between corporate governance and corporate social responsibility, Bocconi University, December 2004.

Bhagwati, J. (2004) In Defence of Globalization, New York: Oxford University Press.

Conroy, M.E. (2001) 'Can Advocacy-Led Certification Systems Transform Global Corporate Practices? Evidence, and Some Theory', Program on Development, Peacebuilding, and the Environment, Political Economy Research Institute (PERI) University of Massachusetts, Amherst, September 2001.

Dasgupta, S., Hong, J.H., Laplante, B. and Mamingi, N. (2004) 'Disclosure of environmental violations and the stock market in the Republic of Korea', World Bank Policy Research working paper 3344, June 2004.

Dasgupta, S., Laplante, B. and Mamingi, N. (2001) 'Pollution and capital markets in developing countries', Journal of Environmental Economics and Management 42: 310-335.

Dowell, G., Hart, S. and Yeung, B. (2000) 'Do corporate global environmental standards create or destroy market value?' Management Science 46: 1059-1074.

Friedman, M. (1971) 'The Social Responsibility of Business is to Increase its Profits', The New York Times Magazine, 13 September 1970.

Geczy, C.C., Stambaugh, R.F. and Levin, D. (2003) 'Investing in socially responsible mutual funds', working paper, The Wharton School of the University of Pennsylvania, May 2003.

Greenfield, Z. (2004) 'The Equator principles: A new industry framework for environmental and social standards in global project finance lending', Paper based on an internship at Citigroup as part of Columbia Business School's Social Enterprise Program (MBA 05 Columbia Business School). 
Hamilton, J.T. (1995) 'Pollution as news: media and stock market reactions to the toxics release inventory data', Journal of Environmental Economics and Management 28: 98-113.

Harrison, A. and Scorse, J. (2003) 'The Nike Effect: Anti-sweatshop activists and labor market outcomes in Indonesia', working paper, UC Berkeley Department of Agricultural and Resource Economics.

Heal, G. (2000) 'Environmental disaster - not all bad news', Financial Times, 30 October.

Hopkins, M. (2004) 'Corporate social responsibility: an issues paper', working paper No. 27, ILO, Geneva. IMD (2003) 'Monsanto’s Genetically Modified Organisms: The Battle for Hearts and Shopping Aisles', Institute for Management Development, Lausanne, Switzerland.

King, A.A. and Lennox, M.J. (2001) 'Does it really pay to be green? An empirical study of firm environmental and financial performance', Journal of Industrial Ecology 5(1).

Krugman, P. (1999) 'Enemies of the WTO: Bogus arguments against the World Trade Organization', http:// slate.msn.com/id/56497/, posted Wednesday, 24 November at 12:30 AM PT.

Livesey, S. (1993) 'McDonald's and the Environment (A)', Harvard Business Case School 9-391-108.

Magretta, J. (1997) 'Growth through global sustainability: an interview with Monsanto's CEO Robert Shapiro', Harvard Business Review on Business and the Environment, chapter 3, Boston, MA: Harvard Business School Publishing.

Montgomery, D.B. and Ramus, C.A. (2003) 'Corporate social responsibility reputation effects on MBA job choice', Research Paper No. 1805, Stanford Graduate School of Business, May 2003.

OECD (2003) 'Guidelines for multinational enterprises', www.oecd.org/daf/investment/guidelines.

Reinhardt, F. (2000) 'Global Climate Change and BP Amoco', Harvard Business School Case N9-700-106.

Reitz, H. (2000) 'Charles Veillon, S.A. (A)', Harvard Business School Case 9-398-011.

The Business Enterprise Trust (1991) 'Merck \& Co., Inc A, B, C and D', Case 9-99-021.

The Economist (2003) 12 December.

The Economist (2004) 4 November, in "Corporate Storytelling".

Vagelos, P.R. and Galambos, L. (2004) Medicine Science and Merck, New York: Cambridge University Press.

Vietor, R. and Reinhardt, F. (1995) 'Starkist (A)', Harvard Business School Case 9-749-128.

Watkins, M. (2003) 'Robert Shapiro and Monsanto', Harvard Case 9-801-4266 January 2, 2003.

\section{About the Author}

Geoffrey Heal is Paul Garret Professor of Public Policy and Corporate Responsibility, Columbia Business School. 